\title{
Dysbiosis in Children Born by C-Section
}

Guest Editors

Alfredo Guarino, Naples

Yuichiro Yamashiro, Tokyo

4 figures, 2 in color and 1 table, 2018 


\section{Sponsor Note}

This publication was supported by an unrestricted educational grant by Probiotics Research Laboratory, Juntendo University, Tokyo, Japan. The institute is a not-for-profit association which was created to provide latest medical and scientific information to health professionals in the field of pediatric and adult nutrition and nutrition-related disorders. Any liability of the sponsors for the content of the papers is hereby expressly excluded.

\section{Disclosure Statement Guest Editors}

Y. Yamashiro has received research grant from Yakult Honsha Co. Ltd., but no conflicts of interest. A. Guarino has received honoraria for his participation on the board of Biocodex France. He has also received a research grant from Dicofarm.

\section{S. Karger}

Medical and Scientific Publishers Basel $\cdot$ Freiburg $\cdot$ Paris $\cdot$ London . New York · Chennai · New Delhi . Bangkok $\cdot$ Beijing $\cdot$ Shanghai $\cdot$ Tokyo . Kuala Lumpur· Singapore $\cdot$ Sydney

\section{Disclaimer}

The statements, opinions and data contained in this publication are solely those of the individual authors and contributors and not of the publisher and the editor(s). The appearance of advertisements in the journal is not a warranty, endorsement, or approval of the products or services advertised or of their effectiveness, quality or safety. The publisher and the editor(s) disclaim responsibility for any injury to persons or property resulting from any ideas, methods, instructions or products referred to in the content or advertisements.

Drug Dosage

The authors and the publisher have exerted every effort to ensure that drug selection and dosage set forth in this text are in accord with current recommendations and practice at the time of publication. However, in view of ongoing research, changes in government regulations, and the constant flow of information relating to drug therapy and drug reactions, the reader is urged to check the package insert for each drug for any change in indications and dosage and for added warnings and precautions. This is particularly important when the recommended agent is a new and/or infrequently employed drug.
All rights reserved.

No part of this publication may be translated into other languages, reproduced or utilized in any form or by any means, electronic or mechanical, including photocopying, recording, microcopying, or by any information storage and retrieval system, without permission in writing from the publisher or, in the case of photocopying, direct payment of a specified fee to the Copyright Clearance Center (see 'General Information').

(C) Copyright 2018 by S. Karger AG,

P.O. Box, CH-4009 Basel (Switzerland)

Printed on acid-free and non-aging paper (ISO 9706)

ISBN 978-3-318-06391-2

e-ISBN 978-3-318-06392-9

\section{KARGER}




\section{Nutrition\& Metabolism}

\section{Contents}

Editorial

1 Caesarean-Section and Neonatal Gut Microbiome: Short and Long Term Effects and New Targets for Early Prevention

Giannattasio, A.; Guarino, A. (Naples)

Review Articles

4 Gut Microbiota Composition in Healthy Japanese Infants and Young Adults Born by C-Section

Nagpal, R. (Winston-Salem, NC/Tokyo); Yamashiro, Y. (Tokyo)

12 Birth Mode-Related Differences in Gut Microbiota Colonization and Immune System Development

Francino, M.P. (Valencia/Madrid)

17 C-Section and the Neonatal Gut Microbiome Acquisition: Consequences for Future Health

Arboleya, S. (Villaviciosa/Oviedo); Suárez, M.; Fernández, N.; Mantecón, L.; Solís, G. (Oviedo); Gueimonde, M.; de los Reyes-Gavilán, C.G. (Villaviciosa/Oviedo)

24 Dysbiosis in Children Born by Caesarean-Section

Salas Garcia, M.C.; Yee, A.L.; Gilbert, J.A. (Chicago, IL); Dsouza, M. (Boston, MA)

33 Intervention for Dysbiosis in Children Born by C-Section

Francavilla, R.; Cristofori, F.; Tripaldi, M.E.; Indrio, F. (Bari) 
